\title{
Maternity Nurses' Performance Regarding Management of the Intrapartum Woman With Cardiac Disease
}

\author{
Eman Mohammed Abd-Elhakam ${ }^{1} \&$ Amira Mohammed Salama ${ }^{1}$ \\ ${ }^{1}$ Obstetrics and Woman's Health Nursing, Faculty of Nursing, Benha University, Egypt \\ Correspondence: Amira Mohammed Salama, Obstetrics and Woman's Health Nursing, Faculty of Nursing, \\ Benha University, Egypt.
}

Received: September 26, 2018

Accepted: October 17, 2018

Online Published: October 29, 2018

doi:10.20849/ijsn.v3i3.498

URL: https://doi.org/10.20849/ijsn.v3i3.498

\begin{abstract}
Background: Cardiac disease in pregnancy is a leading cause of maternal and neonatal morbidity and mortality. Effective management is based upon close fetal and maternal monitoring during pregnancy and labour. The aim of the present study was to evaluate maternity nurses' performance regarding management of intrapartum woman with cardiac disease. Research design: A quasi-experimental design was utilized to fulfil the aim of the study. Sample: A convenient sample of a total 64 maternity nurses was included in the present study. Setting: The present study was conducted in Obstetrical and Gynecological Department at Benha University Hospital. Tools: Two tools were utilized for data collection. I-A structured interviewing questionnaire which include two parts; Part 1: Socio demographic characteristics. Part2: Assessment of nurses' knowledge regarding cardiac disease during pregnancy and labour which includes Physiological changes of cardiovascular system during pregnancy. Causes and risk factors, etc. II-Maternity nurses' practice observational checklistwhich focus on management of cardiac women during labor including four stages of labour and Nursing care for moderate and high risk cases immediately after labour. Results: Shows significant improvement in nurses' knowledge $57.8 \%$ compared to $90.6 \%$ post intervention. Also, improvement is clear in satisfactory level of practice after intervention, in first stage for example was $32.8 \%$ pre intervention compared to $87.5 \%$ post intervention. there were highly statistical significance differences between mean score of both knowledge and practice regarding management of intrapartum woman with cardiac diseases between the pre and post intervention phases $(\mathrm{p}<0.001)$.Conclusion: the study concluded that research hypotheses are supported and educational intervention had appositive effect on improvement nurses 'knowledge and practice and in turn their performance regarding management of intrapartum woman with cardiac diseases. Recommendation: Periodic educational program for nursing staff in Obstetrics and Gynecology Department regarding nursing care of cardiac patients.
\end{abstract}

Keywords: maternity nurse, performance, intrapartum management, cardiac disease

\section{Introduction}

Cardiac disease during pregnancy is still one of the critical medical conditions with serious complications and leading to indirect cause of maternal death, complicates $1 \%$ to $4 \%$ of all pregnancies and is responsible for $10 \%$ to $15 \%$ of maternal mortality. Although its prevalence is considered relatively low in pregnant women, heart disease remains a significant cause of maternal death worldwide (Michael \& Kathleen, 2014). Cardiac disease with Pregnancy not only poses a risk of maternal mortality but also of serious morbidity such as heart failure, stroke and cardiac arrhythmia. The fetus is not spared: neonatal morbidity and mortality from fetal growth retardation and prematurity are markedly increased. Adverse neonatal outcome occurs in 20-28\% of pregnancies in women with heart disease (Gelson, 2011).

The worldwide maternal mortality rate in pregnant cardiac patients is $10 \%$ the numbers of women who have a pre-existing cardiovascular disease or develop cardiac problems during pregnancy are increasing, $28 \%$ of all indirect obstetric deaths are caused by heart disease. The incidence of maternal Cardiac disease appears to be in growing, likely due to increasing maternal age, cardiovascular risk factors (i.e., obesity, diabetes, and hypertension, smoking and previous illicit drug used),furthermore, improved life expectancy of women born with congenital cardiac disease and increased immigration revealing an in rheumatic heart disease adds to the prevalence causes of cardiac disease in pregnancy include congenital lesions, stenoticvalvular lesions, myocardial infarction, and primary pulmonary hypertension. Cardiac conditions usually require consultation and 
collaboration with a cardiologist who is knowledgeable about the physiologic changes caused by pregnancy (Steer., et al 2012).

During a normal pregnancy the maternal cardiovascular system undergoes many changes that place a physiologic strain on the heart. Including increases in circulating blood volume, plasma volume, heart rate, and cardiac output. This is usually well tolerated by healthy mothers but may not be by women with preexisting cardiac disease who have inadequate cardiovascular reserve. During labor and delivery, additional hemodynamic changes including increased heart rate, arterial pressure, central venous pressure, and cardiac output place additional stress on the maternal heart particularly during uterine contraction. Pregnancy may also lower the threshold for rhythm disturbances. The woman with cardiac disease is challenged by these changes and becomes at risk for cardiac decompensation and complications that include congestive heart failure, arrhythmias, and stroke (MporarBrickner, 2018).

Women with risk factors for an adverse labour outcome that are known before the onset of labour will enter labour with a plan of care that includes the place of birth, level of intrapartum maternal and fetal monitoring, strategies for intrapartum analgesia and treatment and interventions specific to the woman's condition. The woman is also likely to have made an individualized birth plan detailing her preferences for labour (Guideline scope, 2015).New York Heart Association classify symptoms of cardiac disease into four functional classes: Class I with ordinary physical activity, Class II with slight limitation of physical activity, Class III marked limitation of physical activity, Class IV: Inability to carry on any physical activity. Class I and II are low risk on the other hand class III and class IV are high risk cases who need close monitoring during labour (Clinical practice guideline, 2016).

The management of the intrapartum woman with cardiac disease presents a unique challenge to healthcare providers. Appropriate care should be supervised by a multidisciplinary team which includes obstetricians, cardiologists, anesthetists, neonatologists and qualified nurses. This requires close collaboration between tertiary cardiac and high risk obstetric services. The ideal labor for women with heart disease is short and pain free, avoid prolonged or difficult labor to lowest risk of complication. In general, vaginal delivery under epidural anaesthesia is preferable (Whitte, et al. 2015). Because bacteremia is common at the time of vaginal delivery and cesarean deliveries many practitioners will provide antibiotic prophylaxis in all patients at risk especially the patient with cardiac diseases (Deen et al., 2017).

Nurses play important role in managing cardiac women during labour though monitoring progress of labour and early detection of possible complications, to ensure best outcomes for both the mother and infant. The main goal of healthcare team is the successful, uncomplicated birth of a new infant. To achieve this, deliver the infant with the least amount of cardiac effort as possible. The second stage of labor should be as short as possible, with interventions aimed at keeping the mother relaxed and unstressed. The labor and delivery nurse is a critical component of the healthcare team, especially in high-risk situations. Evaluation of maternal blood pressure, heart rate and hemoglobin arterial oxygen saturation is routinely incorporated into the labor assessment of a patient with any cardiac compromise. Maternal evaluation is individualized on the basis of the specific cardiac lesion and the potential for existence of any decompensation. Continuous fetal heart rate monitoring (FHM) is usually a recommended standard of care for the laboring woman with cardiac concerns (RCOG, 2011).

\subsection{Significance of the Study}

The incidence of maternal cardiovascular disease appears to be growing, likely due to increasing maternal age, cardiovascular risk factors and lifespan of patients with congenital heart disease. Cardiovascular disease complicates up to 4 percent of pregnancies. Two thirds of maternal deaths from heart disease occur during or shortly after labour' (Andersen \& Hythe, 2016). In Egypt 16\% of maternal deaths are due to heart diseases during pregnancy. This percentage means that heart disease during pregnancy is the fourth most common cause of maternal mortality following hemorrhage, sepsis, and hypertensive diseases (WHO., 2016).

Therefore, women with pre-existing cardiac disease and those who present with cardiac disease during pregnancy require nurses equipped with professional performance in specialist assessment and management during pregnancy, labour and the postpartum period. A successful outcome for women with heart disease requires specialized care. Proactive, preventative nursing is the best defense in decreasing maternal or fetal morbidity and mortality. Maternal-fetal assessments must be continuous, with a clinical focus on maternal and infant stabilization. Perinatal nurses must be prepared for the prospect of an intrapartum emergency at any time. (Pieper, 2012). Also; There is no study was done regarding management of the intrapartum woman with cardiac diseasein maternal and neonatal health nursing department at faculty of nursing Benha university at this time therefore this study will be conducted. 


\subsection{Aim of the Study}

The present study was aimed to evaluate maternity nurses' performance regarding management of intrapartum woman with cardiac disease.

This aim was achieved through the following objectives:

1-Assessing knowledge of maternity nurses regarding cardiac disease during pregnancy.

2-Assessing practice of maternity nurses regarding management of intrapartum woman with cardiac disease.

3-Designing and implementing an educational intervention regarding management of intrapartum woman with cardiac disease.

4-Evaluating the outcome of an educational program on performance of maternity nurses regarding management of intrapartum woman with cardiac disease.

\subsection{Research Hypotheses}

H1-Maternity nurses exhibit higher knowledge score after participating in educational interventionprogram regarding management of intrapartum woman with cardiac disease than before.

H2-Maternity nurses exhibit higher practices score after participating in educational intervention program regarding management of intrapartum woman with cardiac disease than before.

\section{Materials and Method}

\subsection{Materials}

\subsubsection{Design}

Quasi experimental design was used (pre/post-test design), single group was studied.

\subsubsection{Setting}

The study was conducted in Obstetrical and Gynecological Departmentat Benha University Hospital.

\subsubsection{Sampling}

Type: A convenient sample.

Size: Total nurses work inObstetrical and Gynecological department at Benha University Hospital (64nurses) at time of data collection.Qalubeya Governorate, Egypt.

\subsubsection{Tools of data Collection}

Two tools were utilized for data collection, prepared by the researchers after reviewing related literature and tested by a panel of experts for validity.

Tool 1: A structured interviewing questionnaire: include two parts; Part 1: Socio demographic characteristics of the study nurses: included (Age, educational level, years of experience, previous training program). Part2: Assessment of nurses' knowledge regarding cardiac disease during pregnancy and labour which includes physiological changes of cardiovascular system during pregnancy, causes and risk factors, clinical picture, maternal and fetal complications in pregnant women with cardiac disease. Examination and management of cardiac pregnant woman. Lastly, after assessment of nurses' knowledge they asked about source of information.

\section{Scoring system:}

The questions were scored as the following; score (1) was given for the correct answer, score (0) was given for the incorrect answer before and after application of the program. The scores of total knowledge were considered as equal or more than $75 \%$ was adequate and less than $75 \%$ was in adequate.

Tool II: Maternity nurses' practice observational checklist: it was adapted from the (Clinical practice guideline, Heart disease in pregnancy, $2^{\text {nd }}$ edition, 2016). This guideline present best clinical practice in the management of heart disease during pregnancy, labour and post-partum. The researchers focus their work on management of cardiac women during labour including four stages of labour and Nursing care for moderate and high risk cases immediately after labour. 


\section{Scoring system:}

The checklist items were scored (1) for done each step correctly while (0) score was given for incorrect or not done. The scores of total practice were considered as $>75 \%$ was satisfactory and $\leq 75 \%$ was unsatisfactory.

\subsection{Method}

The study was executed according to the following steps:

\section{- Approval:}

An official permission was obtained from both dean of Benha Faculty of Nursing and the hospital authorities in the identified setting to collect the necessary data and implement the program.

- The pilot study: The pilot study was conducted on $10 \%$ (6 nurses) for a period of two weeks to test the clarity and the applicability of the tool, find out the possible obstacles and problems that might face the researchers and interfere with data collection. The study sample included in the pilot study was included also into the study due to no modification done in the tool.

\section{- Tools Validity:}

The developed tool was reviewed for appropriateness of items and measuring the concepts through three an expert jury panel in the field of maternity nursing, obstetric medicine and cardiac medicine specialty to assure content validity. The questionnaires were modified according to the panel judgment on clarity of sentences and appropriateness of content.

\section{- Tools reliability:}

The reliability was done by Cronbach's Alpha coefficient test which revealed that each of the two tools consisted of relatively homogenous items as indicated by the moderate to high reliability of each tool. The internal consistency of knowledge was 0.78 ; While internal consistency of practice was 0.81 .

\section{- Ethical considerations:}

All ethical issues were considered, participants were given explanations about the purpose of the study, and they were also informed that they could withdraw from the study at any time before the completion of the study. Participants who agreed to complete in this study were asked to sign a consent form.

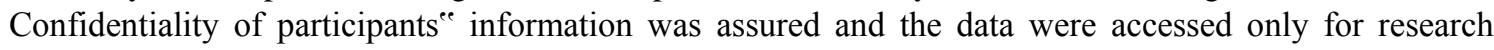
purpose

\section{- Field work (procedure):}

\section{1- Assessment phase:}

Nurses were assessed for their needs prior implementation of the educational program regarding management of cardiac pregnant women during labour.

\section{2- Planning phase:}

The content of the program was designed to meet the following objectives:

\section{General objective:}

At the end of educational program sessions each nurse should be able to acquire essential knowledge and practice needed to provide professional care to women with cardiac disease during labour.

\section{Specific objectives:}

At the end of program sessions each nurse should be able to

1-Describe anatomy and Physiology of cardiovascular system.

2-List causes and risk factors of cardiac disease during pregnancy.

3- Recognize diagnosis and clinical picture of cardiovascular disease during pregnancy.

4-Describe functional classification of heart disease (class I, II, III, IV).

5- List impact of existing cardiac disease on the pregnancy and labour

6- Explain safe medications during pregnancy.

7- List maternal complications in pregnant woman with cardiac disease (the most common heart failure, arrhythmias).

8-Explain effects of labor on the cardiovascular system.

9- List indications for cesarean section. 
As well as the nurses should be able to practice proficiently all procedures related to management of cardiac pregnant woman during labour.

\section{3-Implementationphase:}

The nursing educational program was carried out in Obstetrical and Gynecological Department at Benha University Hospital after taking permission from both dean of Benha Faculty of Nursing and director of Benha Hospital based on the results obtained from assessment phase, the researchers visit the setting 2 days per week (Saturday and Wednesday) from 9.am to 2.p.m starting from the beginning of March 2018 till the end of august 2018 covering six months. Firstly: The researchers introduce themselves and explain aim of the study and ethical consideration to nurses and after their approval pretest was done through distributing interviewing questionnaires to assess socio demographic characteristics and their knowledge regarding management of cardiac women during labour, this tool took about 10-15 min. Then the researchers assessed practices of nurses using tool II while caring of these women, this tool took about 20 minutes. The total study sample of nurses completed within two month. Secondly: Health education program regarding "management of cardiac women during labour' was implemented to the nurses. The total sample was classified into 10 groups each group about 6-7nurses, and each group obtained 6 sessions ( 2 theory and 4 practical),total time needed 5-6 hours for each group weekly (1 hour per session ). Explanation of educational program was facilitated by using power point presentation, discussion, demonstration and redemonstrations using simple, brief and clear words. At the end of each session, a brief summary was given by the researchers, emphasized the most important points included in each session.

Theoretical sessions: There were two sessions included the following;

-One session was given to cover knowledge about; the general and specific objectives of guidelines, definition of cardiovascular system, anatomy and physiology of cardiovascular system during pregnancy, causes and risk factors, clinical picture and functional classification of

-Another session was given to cover knowledge about safe medications during pregnancy maternal and fetal complications in pregnant women with cardiac disease, mode of delivery. Indications for cesarean section and type of anaesthesia that prefered

Practical sessions: were carried out in (4) sessions, to cover practical part of management of intrapartum woman with cardiac disease as: clinical practice in the management of intrapartum woman with cardiac diseases during first, second, third, fourth stages of labour and postpartum care. Before begining of each session, maternity nurses were asked questions related to the topics discussed in the previous session to ensure that they remember the instruction given and to reinforce the knowledge, missed or unclear points were re-emphasized by researchers.

booklet about management of intrapartum woman with cardiac disease was given to each maternity nurse in the study group to grasp her attention, motivate her, help for reviewing at home and support teaching and practicing.

\section{4-Evaluationand follow up phase:}

- During this phase, the effect of educational program was evaluated by using the same format of tools which used before the program implementation.

- Evaluation of maternity nurses "knowledge using tool 1 and maternity nurses "practice using tool 11 (post-test).

\section{Statistical Analysis:}

Data were collected, entered and analyzed by using SPSS (version 20) software computer package (special package for social science) presented in tabular form. Percentages were calculated for qualitative data and $\mathrm{x} 2$ for test of significance, mean and standard deviations were calculated for quantitative data Chi Square (X2), t-test, ANOVA ( $F$ test), paired t-test and correlation coefficient ( $r$ ) were used when appropriate. P-Value $<0.05$ was considered to be statistically significant.

\section{Limitation of the study:}

Lack of local researches that study the current research

\section{Results}

Table 1: Reveals that nearly half of the studied maternity nurses were aged ( $<30$ years). The highest percentage $(59.4 \%)$ of them had a diploma nursing education. Moreover $39.1 \%$ of them had less than five years of 
experience. In addition the majority (95.3\%) of them hadn't training courses regarding management of intrapartum woman with cardiac diseases.

Figure 1: Shows that more than half of studied nurses $(64.1 \%)$ had their source of information from work experience and only 4.7 of them from training courses about management of intrapartum woman with cardiac diseases

Table 2: Shows that, there was a highly statistically significant difference between mean scores of knowledge regarding management of intrapartum woman with cardiac diseases between the pre and post intervention phases $(\mathrm{p}<0.001)$.

Figure 2: Represents that total knowledge score of studied nurses regarding management of intrapartum woman with cardiac diseases were improved $90.6 \%$ compared to $57.8 \%$ pre intervention.

Table 3: Shows that, there was a highly statistically significant difference between mean scores of clinical practice in the management of intrapartum woman with cardiac diseases during first stage between the pre and post intervention phases $(\mathrm{p}<0.001)$. While there was no statistically significant difference between mean scores of the item (Assessment of vital signs every 30 minute) between the pre and post intervention phases.

Table 4: Shows that, there was a highly statistically significant difference between mean scores of clinical practice in the management of intrapartum woman with cardiac diseases during second stage between the pre and post intervention phases $(\mathrm{p}<0.001)$. While The practice of nurses related to (Active pushing limited, preferring The lateral decubitus position, Appling sterile dressing on the perineum with pressure during crowning \& Cesarean section should be reserved for complicated cases improved with no significant difference $(\mathrm{p}>0.05)$

Table 5: Shows that, there was a highly statistically significant difference between mean scores of clinical practice in the management of intrapartum woman with cardiac diseases during third stage between the pre and post intervention phases $(\mathrm{p}<0.001)$. While the practice of nurses related to (Observe signs of placental separation.) improved from 62.5to 76.6 with no significant difference ( $p>0.05)$.

Table 6: Shows that, there was a highly statistically significant difference between mean scores of practice in the management of intrapartum woman with cardiac diseases during fourth stage between the pre and post intervention phases $(\mathrm{p}<0.001)$.

Figure 3: Represents that total practice score of studied nurses regarding management of four stages of labour of woman with cardiac diseases were improved after intervention than pre intervention

Table 7: Shows that, there was a highly statistically significant difference between mean score of practice in the management of woman with cardiac diseases during postpartum stage between the pre and post intervention phases $(\mathrm{p}<0.001)$.

Figure 4: Represents that total practice score regarding management of postpartum stage and complications of postpartum stage of client with cardiac diseases were improved after intervention than pre intervention.

Table 8: Illustrates that, there was a highly statistically significant difference between total practice score related to management of fourth stages, postpartum stage and complications of postpartum stage of woman with cardiac diseases between the pre and post intervention phases $(\mathrm{p}<0.001)$.

Table 9: Shows the correlation between studied nurses' knowledge and practice scores at different phases of intervention, it was observed that there was a highly positive association between their knowledge and practice scores at pre and post intervention phase. 
Table 1. Distribution of studied nurses according to socio-demographic characteristics $(\mathrm{n}=64)$

\begin{tabular}{|c|c|c|}
\hline Socio-demographic characteristics & No & $\%$ \\
\hline \multicolumn{3}{|l|}{ Age } \\
\hline - <30years & 31 & 48.4 \\
\hline - 30-<40years & 24 & 37.5 \\
\hline - $>40$ years & 9 & 14.1 \\
\hline Mean \pm SD & \multicolumn{2}{|c|}{$32.6 \pm 4.53$} \\
\hline \multicolumn{3}{|l|}{ Qualification } \\
\hline - Diploma nursing & 38 & 59.4 \\
\hline - Nursing institute & 18 & 28.1 \\
\hline - Nursing college & 5 & 7.8 \\
\hline - Master & 2 & 3.1 \\
\hline - $\mathrm{PHD}$ & 1 & 1.6 \\
\hline \multicolumn{3}{|l|}{ Current job } \\
\hline - Nurse & 46 & 71.9 \\
\hline - Nursing Specialist & 12 & 18.8 \\
\hline - Supervisor & 6 & 9.4 \\
\hline \multicolumn{3}{|l|}{ Years of experience } \\
\hline - $<5$ years & 25 & 39.1 \\
\hline - >5years & 39 & 60.9 \\
\hline \multicolumn{3}{|l|}{ Training courses } \\
\hline - Yes & 3 & 4.7 \\
\hline - $\mathrm{No}$ & 61 & 95.3 \\
\hline
\end{tabular}

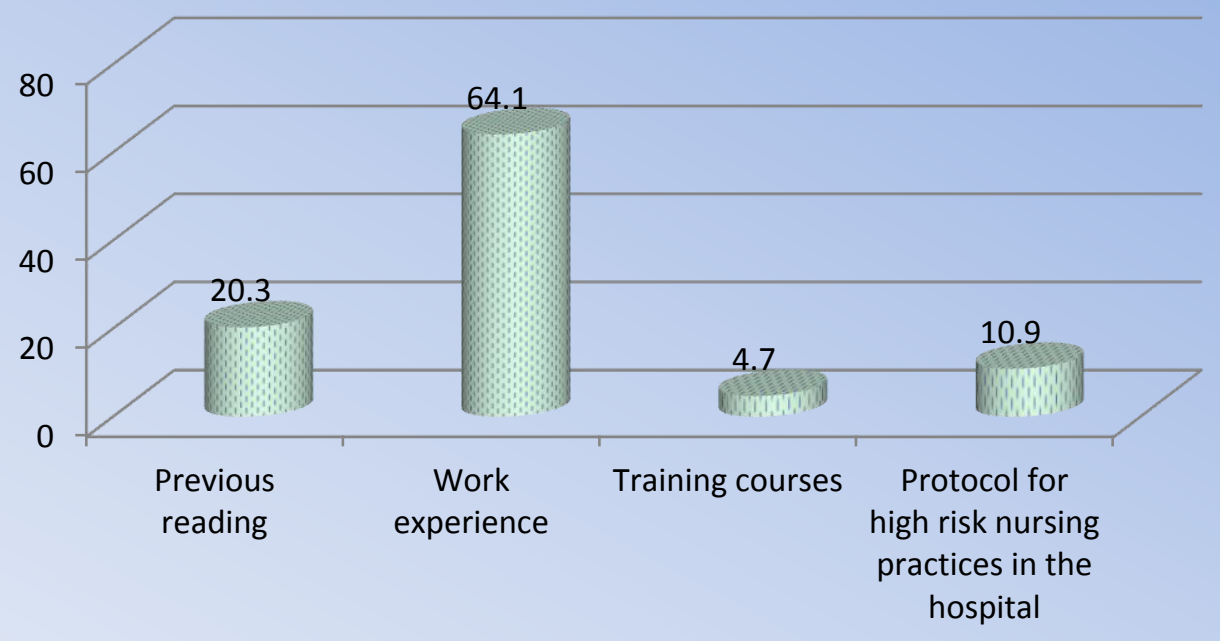

Figure 1. Frequency distribution of studied nurses regarding their source of information about management of intrapartum woman with cardiac diseases 


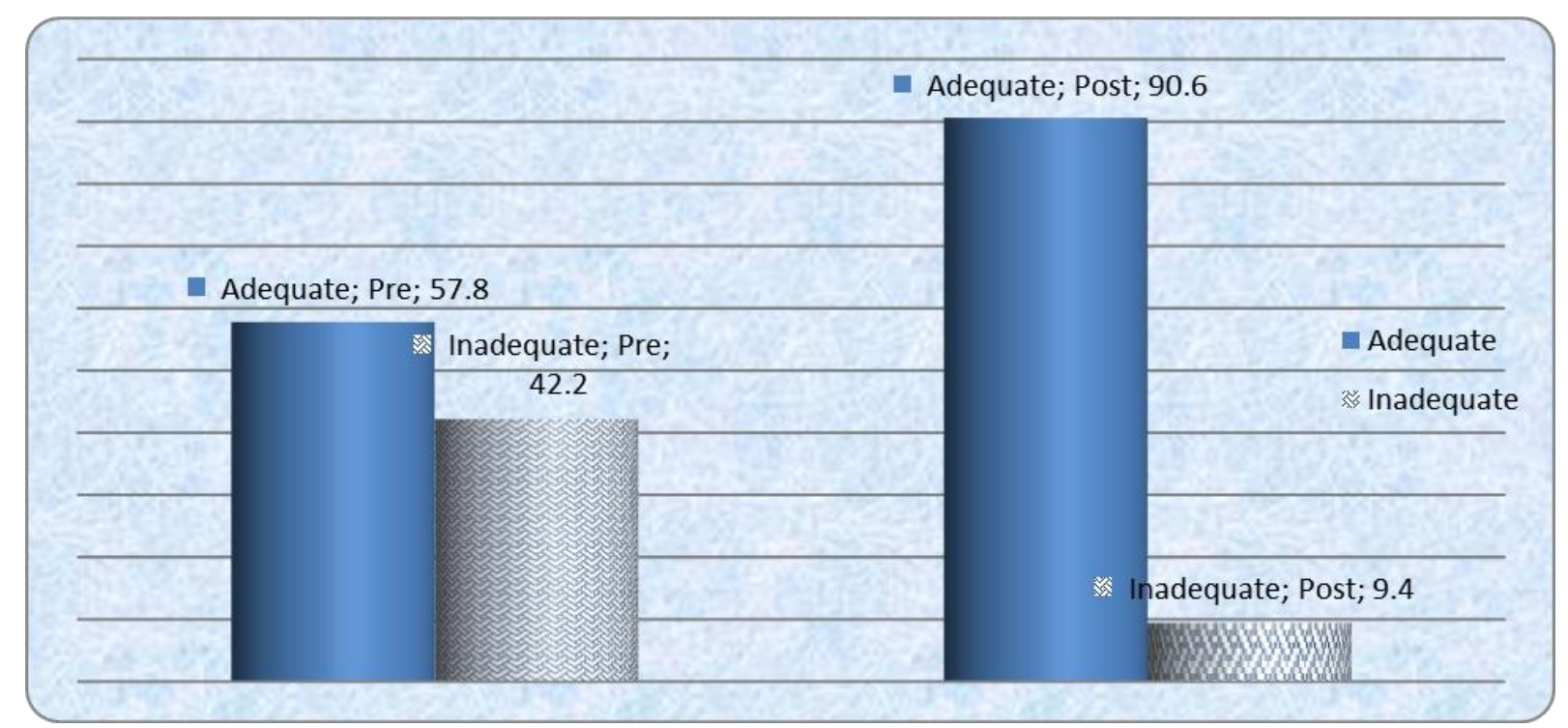

Figure 2. Frequency distribution of studied nurses regarding their total knowledge score pre and post intervention

Table 2. Distribution of studied nurses in relation to their knowledge regarding management of intrapartum woman with cardiac diseases $(\mathrm{n}=64)$

\begin{tabular}{|c|c|c|c|c|c|c|c|c|c|c|}
\hline \multirow{3}{*}{ Knowledge } & \multicolumn{4}{|c|}{ Pre-intervention } & \multicolumn{4}{|c|}{ Post-intervention } & \multirow{3}{*}{$\begin{array}{l}\text { Chi } \\
\text { squar } \\
\text { e test }\end{array}$} & \multirow{3}{*}{$\begin{array}{c}\mathbf{P} \\
\text { value }\end{array}$} \\
\hline & \multicolumn{2}{|c|}{ Correct } & \multicolumn{2}{|c|}{ Incorrect } & \multicolumn{2}{|c|}{ Correct } & \multicolumn{2}{|c|}{ Incorrect } & & \\
\hline & NO & $\%$ & NO & $\%$ & NO & $\%$ & NO & $\%$ & & \\
\hline $\begin{array}{l}\text { Anatomy and physiology of } \\
\text { cardiovascular system. }\end{array}$ & 24 & 37.5 & 40 & 62.5 & 44 & 68.8 & 20 & 31.3 & 12.5 & 0.000 \\
\hline $\begin{array}{l}\text { Meaning of cardiac disease during } \\
\text { pregnancy. }\end{array}$ & 13 & 20.3 & 51 & 79.7 & 50 & 78.1 & 14 & 21.9 & 42.7 & 0.000 \\
\hline $\begin{array}{l}\text { Causes of cardiac disease during } \\
\text { pregnancy. }\end{array}$ & 21 & 32.8 & 43 & 67.2 & 51 & 79.7 & 13 & 20.3 & 28.5 & 0.000 \\
\hline $\begin{array}{l}\text { Risk Factors for Adverse } \\
\text { Pregnancy Outcomes. }\end{array}$ & 30 & 46.9 & 34 & 53.1 & 59 & 92.2 & 5 & 7.8 & 31.0 & 0.000 \\
\hline $\begin{array}{l}\text { Clinical picture of cardiovascular } \\
\text { disease during pregnancy. }\end{array}$ & 35 & 54.7 & 29 & 45.3 & 60 & 93.8 & 4 & 6.3 & 25.5 & 0.000 \\
\hline $\begin{array}{l}\text { Follow up schedule visits for high } \\
\text { risk cases during pregnancy. }\end{array}$ & 23 & 35.9 & 41 & 64.1 & 56 & 87.5 & 8 & 12.5 & 36.0 & 0.000 \\
\hline $\begin{array}{l}\text { Diagnosis of cardiac disease } \\
\text { during pregnancy and examination } \\
\text { neede }\end{array}$ & 20 & 31.3 & 44 & 68.8 & 54 & 84.4 & 10 & 15.6 & 37.0 & 0.000 \\
\hline $\begin{array}{l}\text { Functional classification of heart } \\
\text { disease (class I, II, III, IV). }\end{array}$ & 24 & 37.5 & 40 & 62.5 & 45 & 70.3 & 19 & 29.7 & 13.8 & 0.000 \\
\hline $\begin{array}{l}\text { Safe medications during } \\
\text { pregnancy. }\end{array}$ & 15 & 23.4 & 49 & 76.6 & 45 & 70.3 & 19 & 29.7 & 28.2 & 0.000 \\
\hline $\begin{array}{l}\text { Maternal complications in } \\
\text { pregnant woman with cardiac } \\
\text { disease }\end{array}$ & 18 & 28.1 & 46 & 71.9 & 56 & 87.5 & 8 & 12.5 & 46.2 & 0.000 \\
\hline $\begin{array}{l}\text { Fetal outcome in pregnant women } \\
\text { with cardiac disease }\end{array}$ & 15 & 23.4 & 49 & 76.6 & 50 & 78.1 & 14 & 21.9 & 38.2 & 0.000 \\
\hline Mode of delivery & 20 & 31.3 & 44 & 68.8 & 48 & 75.0 & 16 & 25.0 & 24.5 & 0.000 \\
\hline Indications for cesarean section. & 8 & 12.5 & 56 & 87.5 & 55 & 85.9 & 9 & 14.1 & 69.0 & 0.000 \\
\hline Type of anaesthesia that preferred & 17 & 26.6 & 47 & 73.4 & 54 & 84.4 & 10 & 15.6 & 43.2 & 0.000 \\
\hline
\end{tabular}


Table 3. Distribution of studied nurses in relation to their clinical practice in the management of intrapartum woman with cardiac diseases during first stage of labour $(n=64)$

\begin{tabular}{|c|c|c|c|c|c|c|c|c|c|c|}
\hline \multirow{3}{*}{ First stage } & \multicolumn{4}{|c|}{ Pre-intervention } & \multicolumn{4}{|c|}{ Post-intervention } & \multirow{3}{*}{$\begin{array}{c}\text { Chi } \\
\text { squar } \\
\text { e test }\end{array}$} & \multirow{3}{*}{$\begin{array}{c}P \\
\text { value }\end{array}$} \\
\hline & & Correct & & Incorrect & & Correct & & correct & & \\
\hline & NO & $\%$ & NO & $\%$ & NO & $\%$ & NO & $\%$ & & \\
\hline $\begin{array}{l}\text { Ask cardiac women to } \\
\text { labour while lying on their } \\
\text { left side. }\end{array}$ & 44 & 68.8 & 20 & 31.3 & 60 & 93.8 & 4 & 6.3 & 13.1 & 0.000 \\
\hline $\begin{array}{l}\text { Hemodynamic monitoring } \\
\text { of cardiac pregnant patients }\end{array}$ & 30 & 46.9 & 34 & 53.1 & 55 & 85.9 & 9 & 14.1 & 21.8 & 0.000 \\
\hline $\begin{array}{l}\text { Assessment of vital signs } \\
\text { every } 30 \text { minute. }\end{array}$ & 52 & 81.3 & 12 & 18.8 & 58 & 90.6 & 6 & 9.4 & 2.32 & 0.12 \\
\hline Fetal monitoring: & 25 & 39.1 & 39 & 60.9 & 54 & 84.4 & 10 & 15.6 & 27.8 & 0.000 \\
\hline Effective pain relief & 20 & 31.3 & 44 & 68.8 & 59 & 92.2 & 5 & 7.8 & 50.2 & 0.000 \\
\hline Close monitoring & 35 & 54.7 & 29 & 45.3 & 51 & 79.7 & 13 & 20.3 & 9.07 & 0.000 \\
\hline $\begin{array}{l}\text { ECG monitoring through } \\
\text { outlabour }\end{array}$ & 39 & 60.9 & 25 & 39.1 & 60 & 93.8 & 4 & 6.3 & 19.6 & 0.000 \\
\hline Timing of delivery & 22 & 34.4 & 42 & 65.6 & 52 & 81.3 & 12 & 18.8 & 28.8 & 0.000 \\
\hline $\begin{array}{l}\text { Infection control by using } \\
\text { aseptic techniques in each } \\
\text { procedure }\end{array}$ & 48 & 75.0 & 16 & 25.0 & 61 & 95.3 & 3 & 4.7 & 10.4 & 0.000 \\
\hline $\begin{array}{l}\text { Prophylactic antibiotics } \\
\text { according to doctor order }\end{array}$ & 47 & 73.4 & 17 & 26.6 & 62 & 96.9 & 2 & 3.1 & 13.9 & 0.000 \\
\hline
\end{tabular}

A highly statistical significant difference $(\mathrm{P} \leq 0.001)$ No statistical significant difference $(\mathrm{P}>0.05)$

Table 4. Distribution of studied nurses in relation to their clinical practice in the management of intrapartum woman with cardiac diseases during second stage of labour (64)

\begin{tabular}{|c|c|c|c|c|c|c|c|c|c|c|}
\hline \multirow{3}{*}{ Second stage } & \multicolumn{4}{|c|}{ Pre-intervention } & \multicolumn{4}{|c|}{ Post-intervention } & \multirow{3}{*}{$\begin{array}{l}\text { Chi square } \\
\text { test }\end{array}$} & \multirow{3}{*}{$P$ value } \\
\hline & \multicolumn{2}{|c|}{ Correct } & \multicolumn{2}{|c|}{ Incorrect } & \multicolumn{2}{|c|}{ Correct } & \multicolumn{2}{|c|}{ Incorrect } & & \\
\hline & NO & $\%$ & NO & $\%$ & NO & $\%$ & NO & $\%$ & & \\
\hline $\begin{array}{l}\text {-Shorten the second stage of labour } \\
\text { by force psorvacuum extraction }\end{array}$ & 38 & 59.4 & 26 & 40.6 & 49 & 76.6 & 15 & 23.4 & 4.34 & 0.037 \\
\hline $\begin{array}{l}\text {-All observations should be } \\
\text { documented on the partogram. }\end{array}$ & 17 & 26.6 & 47 & 73.4 & 45 & 70.3 & 19 & 29.7 & 24.5 & 0.000 \\
\hline -Bed rest in semi sitting position & 46 & 71.9 & 18 & 28.1 & 55 & 85.9 & 9 & 14.1 & 3.80 & 0.051 \\
\hline $\begin{array}{l}\text {-Induction of labourmay be achieved } \\
\text { mechanically with foley catheter or } \\
\text { using PGE2. }\end{array}$ & 25 & 39.1 & 39 & 60.9 & 51 & 79.7 & 13 & 20.3 & 21.8 & 0.000 \\
\hline $\begin{array}{l}\text {-Spontaneous labour is usually } \\
\text { quicker than induced }\end{array}$ & 15 & 23.4 & 49 & 76.6 & 45 & 70.3 & 19 & 29.7 & 28.2 & 0.000 \\
\hline -Avoid prolonged labour. & 44 & 68.8 & 20 & 31.3 & 52 & 81.3 & 12 & 18.8 & 32.5 & 0.000 \\
\hline -Active pushing should be limited, & 47 & 73.4 & 17 & 26.6 & 49 & 76.6 & 15 & 23.4 & 0.16 & 0.68 \\
\hline $\begin{array}{l}\text {-Vaginal delivery is preferred with } \\
\text { assisted second stage. }\end{array}$ & 20 & 31.3 & 44 & 68.8 & 52 & 81.3 & 12 & 18.8 & 32.5 & 0.000 \\
\hline $\begin{array}{l}\text { - Put oxgen mask or ventilation if } \\
\text { heart failure or cyanosis develop. }\end{array}$ & 26 & 40.6 & 38 & 59.4 & 51 & 79.7 & 13 & 20.3 & 20.3 & 0.000 \\
\hline $\begin{array}{l}\text {-The lateral decubitus position is the } \\
\text { preferred position in labour }\end{array}$ & 43 & 67.2 & 21 & 32.8 & 45 & 70.3 & 19 & 29.7 & 0.14 & 0.70 \\
\hline $\begin{array}{l}\text {-Apply sterile dressing on the } \\
\text { perineum with pressure during } \\
\text { crowning. }\end{array}$ & 48 & 75.0 & 16 & 25.0 & 47 & 73.4 & 17 & 26.6 & 0.04 & 0.84 \\
\hline $\begin{array}{l}\text {-Paediatricteamto be present during } \\
\text { labour. }\end{array}$ & 29 & 45.3 & 35 & 54.7 & 47 & 73.4 & 17 & 26.6 & 10.4 & 0.000 \\
\hline $\begin{array}{l}\text {-Cesarean section should be reserved } \\
\text { for complicated cases }\end{array}$ & 47 & 73.4 & 17 & 26.6 & 49 & 76.6 & 15 & 23.4 & 0.16 & 0.68 \\
\hline
\end{tabular}

A highly statistical significant difference $(\mathrm{P} \leq 0.001)$ 
Table 5. Distribution of studied nurses in relation to their clinical practice in the management of intrapartum woman with cardiac diseases during third stage of labour (64)

\begin{tabular}{|c|c|c|c|c|c|c|c|c|c|c|}
\hline \multirow{3}{*}{ Third stage } & \multicolumn{4}{|c|}{ Pre-intervention } & \multicolumn{4}{|c|}{ Post-intervention } & \multirow{3}{*}{$\begin{array}{l}\text { Chisquar } \\
\text { etest }\end{array}$} & \multirow[t]{3}{*}{$P$ value } \\
\hline & \multicolumn{2}{|c|}{ Correct } & \multicolumn{2}{|c|}{ Incorrect } & \multicolumn{2}{|c|}{ Correct } & \multicolumn{2}{|c|}{ Incorrect } & & \\
\hline & NO & $\%$ & NO & $\%$ & NO & $\%$ & NO & $\%$ & & \\
\hline $\begin{array}{l}\text { Close attention for monitoring } \\
\text { hemostasis during management this } \\
\text { critical period. }\end{array}$ & 37 & 57.8 & 27 & 42.2 & 55 & 85.9 & 9 & 14.1 & 12.5 & 0.000 \\
\hline $\begin{array}{l}\text { Oxytocin is the drug of choice for } \\
\text { active management during third } \\
\text { stage( IM } 5 \text { IU and control cord } \\
\text { traction) }\end{array}$ & 21 & 32.8 & 43 & 67.2 & 54 & 84.4 & 10 & 15.6 & 35.0 & 0.000 \\
\hline $\begin{array}{l}\text { Assess fundus condition to ensure } \\
\text { that is well contracted }\end{array}$ & 37 & 57.8 & 27 & 42.2 & 52 & 81.3 & 12 & 18.8 & 8.29 & 0.004 \\
\hline Identify signs of P.P.Hge. & 28 & 43.8 & 36 & 56.3 & 52 & 81.3 & 12 & 18.8 & 19.2 & 0.000 \\
\hline $\begin{array}{l}\text { Observe signs of placental } \\
\text { separation. }\end{array}$ & 40 & 62.5 & 24 & 37.5 & 49 & 76.6 & 15 & 23.4 & 2.98 & 0.08 \\
\hline $\begin{array}{l}\text { Avoid ergometrine administration } \\
\text { to facilitate delivery of placenta } \\
\text { because it can cause coronary } \\
\text { vasospasm. }\end{array}$ & 19 & 29.7 & 45 & 70.3 & 51 & 79.7 & 13 & 20.3 & 32.2 & 0.000 \\
\hline $\begin{array}{l}\text { Support the placenta in both hands } \\
\text { after its delivery and rotates it in } \\
\text { order to allow the sliding out of the } \\
\text { membranes. }\end{array}$ & 20 & 31.3 & 44 & 68.8 & 55 & 85.9 & 9 & 14.1 & 39.4 & 0.000 \\
\hline Observe the placental lobes & 21 & 32.8 & 43 & 67.2 & 60 & 93.8 & 4 & 6.3 & 51.1 & 0.000 \\
\hline $\begin{array}{l}\text { If oxytocin is used to control } \\
\text { hemorrhage, it should be given by } \\
\text { very slow intravenous infusion. }\end{array}$ & 24 & 37.5 & 40 & 62.5 & 55 & 85.9 & 9 & 14.1 & 31.7 & 0.000 \\
\hline Swab the vulva & 32 & 50.0 & 32 & 50.0 & 59 & 92.2 & 5 & 7.8 & 27.7 & 0.000 \\
\hline Perform perineal care. & 42 & 65.6 & 22 & 34.4 & 57 & 89.1 & 7 & 10.9 & 10.0 & 0.002 \\
\hline
\end{tabular}

A highly statistical significant difference $(\mathrm{P} \leq 0.001)$

Table 6. Distribution of studied nurses in relation to their clinical practice in the management of intrapartum woman with cardiac diseases during fourth stage of labour $(n=64)$

\begin{tabular}{|c|c|c|c|c|c|c|c|c|c|c|}
\hline \multirow{3}{*}{ Fourth stage } & \multicolumn{4}{|c|}{ Pre-intervention } & \multicolumn{4}{|c|}{ Post-intervention } & \multirow{3}{*}{$\begin{array}{c}\text { Chi } \\
\text { square } \\
\text { test }\end{array}$} & \multirow{3}{*}{$P$ value } \\
\hline & \multicolumn{2}{|c|}{ Correct } & \multicolumn{2}{|c|}{ Incorrect } & \multicolumn{2}{|c|}{ Correct } & \multicolumn{2}{|c|}{ Incorrect } & & \\
\hline & NO & $\%$ & NO & $\%$ & NO & $\%$ & NO & $\%$ & & \\
\hline $\begin{array}{l}\text {-Observe women very closely for } \\
24 \text { hours post-partum. }\end{array}$ & 24 & 37.5 & 40 & 62.5 & 50 & 78.1 & 14 & 21.9 & 21.6 & 0.000 \\
\hline -Report signs of cardiac failure. & 39 & 60.9 & 25 & 39.1 & 55 & 85.9 & 9 & 14.1 & 10.2 & 0.000 \\
\hline $\begin{array}{l}\text {-Monitor Respiratory } \\
\text { rate.oxygen saturation }\end{array}$ & 24 & 37.5 & 40 & 62.5 & 52 & 81.3 & 12 & 18.8 & 25.3 & 0.000 \\
\hline $\begin{array}{l}\text {-Take and record the women's } \\
\text { respiration when pulse is taken. }\end{array}$ & 22 & 34.4 & 42 & 65.6 & 45 & 70.3 & 19 & 29.7 & 16.5 & 0.000 \\
\hline $\begin{array}{l}\text {-Continue a semi upright } \\
\text { position. }\end{array}$ & 25 & 39.1 & 39 & 60.9 & 60 & 93.8 & 4 & 6.3 & 42.9 & 0.000 \\
\hline $\begin{array}{l}\text {-Encourage deep breathing and } \\
\text { passive leg exercise. }\end{array}$ & 24 & 37.5 & 40 & 62.5 & 59 & 92.2 & 5 & 7.8 & 41.9 & 0.000 \\
\hline $\begin{array}{l}\text {-Medication should be } \\
\text { recommended as indicated with } \\
\text { breast feeding safety profile. }\end{array}$ & 22 & 34.4 & 42 & 65.6 & 58 & 90.6 & 6 & 9.4 & 43.2 & 0.000 \\
\hline
\end{tabular}




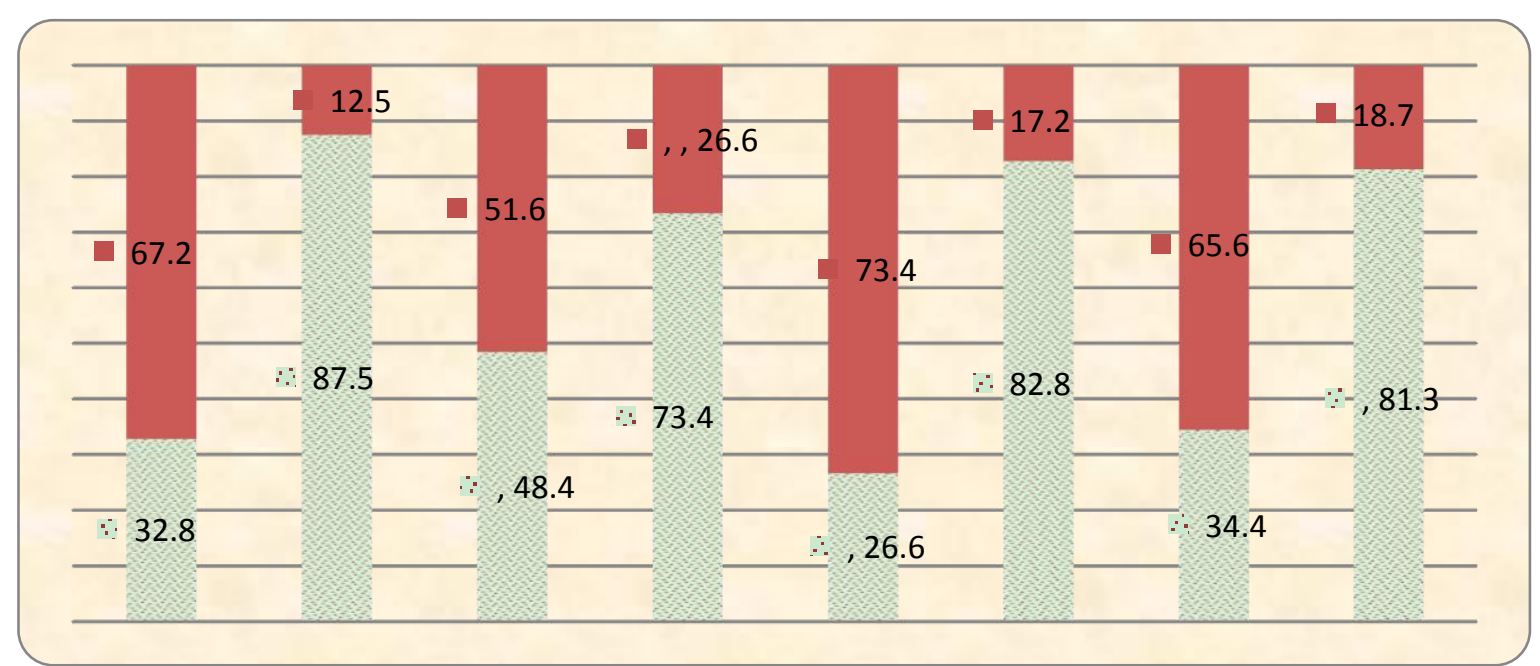

Figure 3. Frequency distribution of studied nurses regarding their total practice score through-out four stages of labourpre and post intervention

Table 7. Distribution of studied nurses in relation to their clinical practice in the management of woman with cardiac diseases during postpartum stage $(n=64)$

\begin{tabular}{|c|c|c|c|c|c|c|c|c|c|c|}
\hline \multirow{3}{*}{ Postpartum stage } & \multicolumn{4}{|c|}{ Pre-intervention } & \multicolumn{4}{|c|}{ Post-intervention } & \multirow{3}{*}{$\begin{array}{l}\text { Chi } \\
\text { square } \\
\text { test }\end{array}$} & \multirow[b]{3}{*}{$\begin{array}{c}\mathbf{P} \\
\text { value }\end{array}$} \\
\hline & \multicolumn{2}{|c|}{ Correct } & \multicolumn{2}{|c|}{ Incorrect } & \multicolumn{2}{|c|}{ Correct } & \multicolumn{2}{|c|}{ Incorrect } & & \\
\hline & NO & $\%$ & NO & $\%$ & NO & $\%$ & NO & $\%$ & & \\
\hline $\begin{array}{l}\text { Monitor the patient in } \\
\text { intensive care unit for the } \\
\text { first } 24-72 \mathrm{hr} \text {. }\end{array}$ & 24 & 37.5 & 40 & 62.5 & 60 & 93.8 & 4 & 6.3 & 44.8 & 0.000 \\
\hline $\begin{array}{l}\text { A minimum length of stay in } \\
\text { hospital of 3-5 days is } \\
\text { recommended. }\end{array}$ & 20 & 31.3 & 44 & 68.8 & 53 & 82.8 & 11 & 17.2 & 34.7 & 0.000 \\
\hline $\begin{array}{l}\text { Detect signs of fluid } \\
\text { overload: Respiratory rate, } \\
\text { Oxygen } \\
\begin{array}{l}\text { saturation, } \\
\text { Input-output charts. }\end{array}\end{array}$ & 26 & 40.6 & 38 & 59.4 & 51 & 79.7 & 13 & 20.3 & 20.3 & 0.000 \\
\hline $\begin{array}{l}\text { Discharge summary should } \\
\text { be given to the patient. }\end{array}$ & 24 & 37.5 & 40 & 62.5 & 60 & 93.8 & 4 & 6.3 & 44.8 & 0.000 \\
\hline $\begin{array}{l}\text { A cardiac follow up } \\
\text { appointment should be given } \\
\text { before discharge. }\end{array}$ & 20 & 31.3 & 44 & 68.8 & 46 & 71.9 & 18 & 28.1 & 21.1 & 0.000 \\
\hline $\begin{array}{l}\text { Contraceptive advice to be } \\
\text { given prior to discharge. }\end{array}$ & 11 & 17.2 & 53 & 82.8 & 55 & 85.9 & 9 & 14.1 & 60.5 & 0.000 \\
\hline Bed rest. & 48 & 75.0 & 16 & 25.0 & 62 & 96.9 & 2 & 3.1 & 12.6 & 0.000 \\
\hline Salt and fluid restriction, & 22 & 34.4 & 42 & 65.6 & 58 & 90.6 & 6 & 9.4 & 43.2 & 0.000 \\
\hline $\begin{array}{l}\text { Diuretics to limit the volume } \\
\text { load and antihypertensive } \\
\text { therapy for after load } \\
\text { reduction. }\end{array}$ & 25 & 39.1 & 39 & 60.9 & 60 & 93.8 & 4 & 6.3 & 42.9 & 0.000 \\
\hline $\begin{array}{l}\text { Angiotensin -converting } \\
\text { enzyme (ACE) inhibitors can } \\
\text { induce fetal anuria, } \\
\text { pulmonary hypoplasia, and } \\
\text { skull deformities. }\end{array}$ & 20 & 31.3 & 44 & 68.8 & 54 & 84.4 & 10 & 15.6 & 37.0 & 0.000 \\
\hline
\end{tabular}

A highly statistical significant difference $(P \leq 0.001)$ 


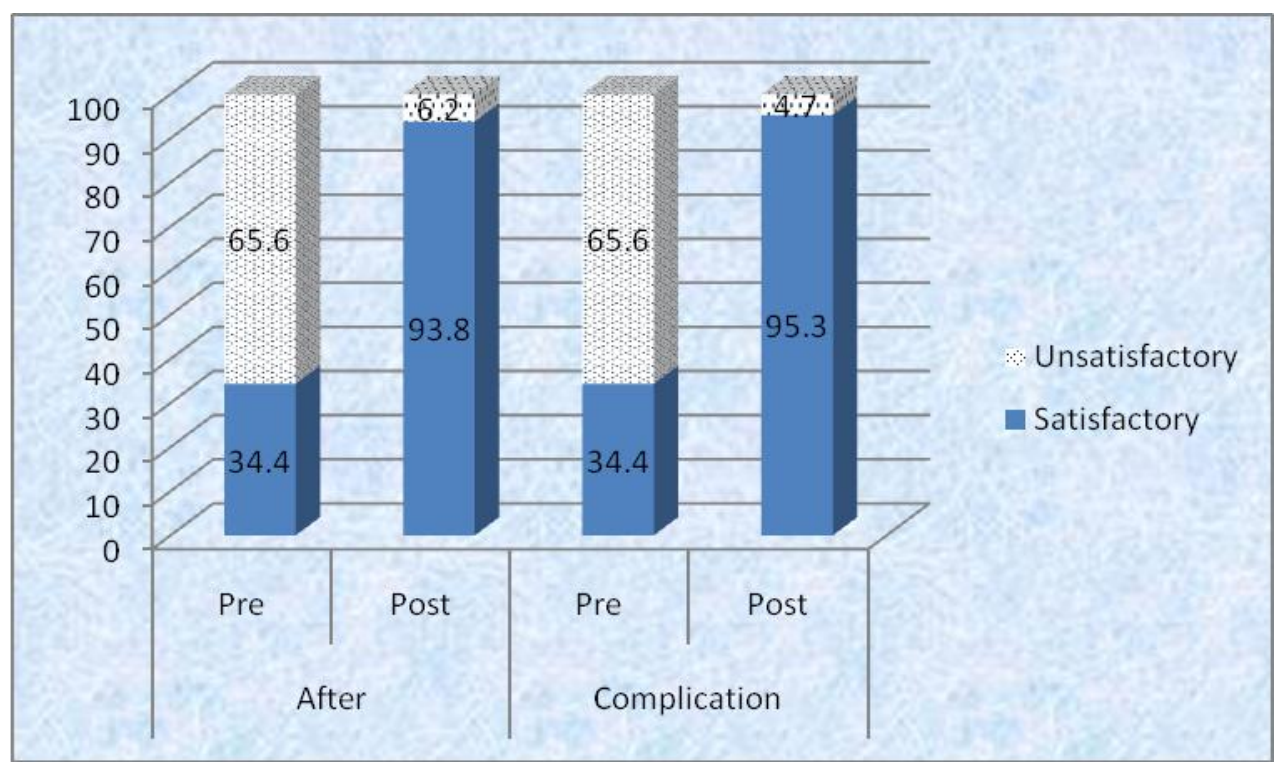

Figure 4. Percentage distribution of studied nurses regarding their total practice score in the management of postpartum stage and complications of postpartum stage of woman with cardiac diseases

Table 8. Frequency distribution of studied nurses regarding their total practice score in the management of fourth stages, postpartum stage and complications of postpartum stage of woman with cardiac diseases

\begin{tabular}{|c|c|c|c|c|c|c|c|c|c|c|}
\hline \multirow{3}{*}{$\begin{array}{c}\text { Total practice } \\
\text { score }\end{array}$} & \multicolumn{4}{|c|}{ Pre-intervention } & \multicolumn{4}{|c|}{ Post-intervention } & \multirow{3}{*}{$\mathrm{X} 2$} & \multirow{3}{*}{ p-value } \\
\hline & \multicolumn{2}{|c|}{ Satisfactory } & \multicolumn{2}{|c|}{ Unsatisfactory } & \multicolumn{2}{|c|}{ Satisfactory } & \multicolumn{2}{|c|}{ Unsatisfactory } & & \\
\hline & No & $\%$ & No & $\%$ & No & $\%$ & No & $\%$ & & \\
\hline First stage & 21 & 32.8 & 43 & 67.2 & 56 & 87.5 & 8 & 12.5 & 39.9 & 0.000 \\
\hline Second stage & 31 & 48.4 & 33 & 51.6 & 47 & 73.4 & 17 & 26.6 & 8.40 & 0.000 \\
\hline Third stage & 17 & 26.6 & 47 & 73.4 & 53 & 82.8 & 11 & 17.2 & 40.8 & 0.000 \\
\hline Fourth stage & 22 & 34.4 & 42 & 65.6 & 52 & 81.3 & 12 & 18.8 & 28.8 & 0.000 \\
\hline After labour & 22 & 34.4 & 42 & 65.6 & 60 & 93.8 & 4 & 6.3 & 49.0 & 0.000 \\
\hline Complication & 22 & 34.4 & 42 & 65.6 & 61 & 95.3 & 3 & 4.7 & 52.1 & 0.000 \\
\hline
\end{tabular}

Table 9. Correlation between total knowledge and total practice of the studied nurses at pre and post intervention phases

\begin{tabular}{|c|c|c|c|c|}
\hline & \multicolumn{4}{|c|}{ Total knowledge } \\
\hline & \multicolumn{2}{|l|}{ Pre } & \multicolumn{2}{|l|}{ post } \\
\hline & $\mathrm{r}$ & $\mathrm{p}$-value & $\mathrm{r}$ & p-value \\
\hline Total practice & 0.55 & 0.05 & 0.70 & 0.000 \\
\hline
\end{tabular}

**. Correlation is significant at the 0.01 level

\section{Discussion}

Women with heart disease are at risk of cardiac complications during pregnancy and delivery. Risk assessment should be performed in these women, and the management of pregnancy and delivery should be planned accordingly (pieper, 2012). Heart disease continues to be the leading cause of non-obstetric maternal morbidity and mortality. Early diagnosis and appropriate care can lead to prevention of complications and improvement of pregnancy outcome (Uri, et al., 2016).

Nurses are extremely important to the care of patients in all aspects of their health. They are constitute the highest number of personnel working in hospital, hence any defect in their role will affect on the quality of care given to the patients, and therefore they require continuous training programs as well as follow-up their care provided to the patients (Laura, et al., 2015). The nurses are in an ideal position to be a health care provider to screen, refer and promote general health. Many times barriers such as inadequate knowledge and skills towards heart disease during pregnancy make defect in the nursing care provided to women. The goal of continuous 
training for nurses is to enhance knowledge, practice, and attitude of them and ultimately to promote the quality of health care delivery to the public (Wald \& Colman, 2017).

Therefore, the aim of this study was to evaluate the effect of educational intervention on maternity nurses' performance regarding management of intrapartum woman with cardiac disease.

The current study shows that more than half of studied nurses had their source of information from work experience and only 4.7 of them from training courses about management of intrapartum woman with cardiac diseases. From researchers point of view this ensure that there were shortage of educational programs and training courses provided for nurses about intrapartum care of pregnant woman with cardiac diseases and also in researchers point of view, providing educational programs is usually better than work experiences as educational programs are usually based on basic correct knowledge and practices which make nurses more knowledgeable and professionally experience.

The present study findings supported the stated hypotheses that an educational intervention will improve maternity nurses' knowledge and Practices regarding management of intrapartum woman with cardiac disease. The present study result represents that total knowledge score of studied nurses regarding management of intrapartum woman with cardiac diseases were improved after intervention than pre intervention. This could be attributed to the fact that any educational intervention increase nurses knowledge in turn changes their practice.

The current study revealed that there was a highly statistically significant difference between mean scores of knowledge regarding management of intrapartum woman with cardiac diseases between the pre and post intervention phases. Similar study conducted by Eman \& Hala (2013) stated that there was a highly statistically significant improvement in knowledge of nurse related to management of heart disease during pregnancy after educational program. This result is in agreement with Centers for Disease control and Prevention,(2015)who illustrated that Pregnancy makes a significant demand on the cardiovascular system Therefore, it follows that women with cardiovascular compromise due to cardiac disease need specialist input and careful management pre-, peri-, and post-partum. This result coincided with Mozaffarian, et al., (2015)who stressed that the training program for nurses personal as method for continuous updating and renewal of their knowledge and skills to maintain and improve competence. This result disagreement with a study by Beth,(2016)who showed increased heart failure knowledge of nurses after viewing an educational video on heart failure the increase was not significant $(\mathrm{p}=0.277)$.

According to findings of the current study there are improvement in the percentages of nurses' practices related to the nursing care of cardiac pregnant patients during first stage of labor which include Lying on left side, measuring vital signs, ECG monitoring, throughout labor after intervention program this finding in the line with Eman\&Hala, (2013)that show improvement in the percentages of nurses' practices related to the nursing care of cardiac pregnant patients during first stage of labor which include measuring vital signs, assessment of respiratory status and oxygen saturation, ECG monitoring throughout labor throughout intervention program. AlsoSunitha et al., (2014) stated that electrocardiography (ECG) is a common and useful diagnostic tool throughout pregnancy for complaints such as chest pain/arrhythmias. Subtle changes in the ECG are common in later pregnancy and include left axis deviation, inverted $\mathrm{T}$ waves and inferior $\mathrm{Q}$ waves due to diaphragmatic elevation.

In the present study the majority of studied nurses in post test encourage cardiac pregnant patients for resting on the left lateral recumbent position in first stage of labor this finding matched with study done byVictor.et al., (2016) who recognized that all women with congenital heart disease should be warned against lying flat during pregnancy, and especially labour, to avoid aortocaval compression (left decubitus position is the position of choice).

The current study revealed that there was a highly statistically significant difference between mean scores of clinical practice in the management of intrapartum woman with cardiac diseases during first stage between the pre and post intervention phases. While there was nostatistically significant difference between mean scores of the item (Assessment of vital signs every 30 minute) between the pre and post intervention phases. In the researchers point of view this may be due to assessing vital signs is a routine nursing care known to all nurses so there was no statistically significant difference after intervention in this item while there was a highly statistically significant difference in all items of first stage which ensure the importance of providing the nurses with instructional programs about the management of intrapartum woman with cardiac diseases during first stage.

Regarding to nurses' practice in the second stage of labour. There was a highly statistically significant difference between mean scores of clinical practice in the management of intrapartum woman with cardiac diseases during 
second stage between the pre and post intervention phases $(\mathrm{p}<0.001)$. While The practice of nurses related to (limiting Active pushing, preferring The lateral decubitus position, Appling sterile dressing on the perineum with pressure during crowning \& Cesarean section should be reserved for complicated cases improved with no significant difference $(\mathrm{p}>0.05)$. In the researchers point of view this may be due to (Limiting active pushing, preferring the lateral decubitus position) are basic and common instruction for woman with heart diseases so there was only improvement with no significant difference. Also the item (applying sterile dressing on the perineum with pressure during crowning) is basic step of management of normal no cardiac woman so there was only improvement with no significant difference between pre-post intervention.

As regard the mode of delivery, it was observed that there was significant improvement in practice throughout intervention program regarding preferring vaginal mode of delivery than cs. In high risk cases, delivery should take place in a tertiary center under specialist multidisciplinary care. No routine endocarditis prophylaxis is necessary. There is no clear consensus regarding absolute contraindications to vaginal delivery. This result is in agreement with Vassilis, (2018), who stated that Cardiovascular conditions that should prompt elective caesarean section consideration are: cases of oral anticoagulation in pre-term labour, Marfan syndrome with aortic diameter $>45 \mathrm{~mm}$ (class IIaC), or 40-45mm (IIbC), acute or chronic aortic dissection, severe intractable heart failure, Eisenmenger syndrome and aortic stenosis (in some centers) Valianiet al.,(2016). Also Esteves-Pereira, et al., (2016) reported that Caesarean section is associated with more profound and sudden haemodynamic changes, greater blood loss, increased risk of infection and dramatically increased risk of venous thromboembolism.

Additionally women with cardiovascular disorders have for many years been subject to a higher rate of Caesarean sections compared to other women, and it has been suspected that this is due to a clinician's perception of the risk involved in changing to an emergency Caesarean section (Ruys et al., 2015). Furthermore, a Caesarean section will significantly affect the mode of future deliveries. The combination of a carefully titrated combined spinal-epidural, passive second-stage and assisted delivery with forceps allow a "pain free, pushing free labour" that is more physiological and safer for the mother (Emmanuel Y, \&Thorne 2015).However, it must be done in experienced hands by a specialist team. Caesarean section is reserved for obstetric indications; in rare cases, if there is a very high risk of aortic dissection, a planned delivery in theatres with a cardiac surgeon on stand-by is recommended.

The overall percentages of correct practices related to nursing care of cardiac women during third and fourth stage of labor, before the intervention program and increase after the intervention program. This ensure that the nurses are responsible to make the mother in labor feel comfortable, guide her through the entire delivery and take care of her and her newborn till they leave the hospital. These nurses are educated to handle emergencies during the course of labor and delivery.

The third stage of labour is usually facilitated by the administration of syntometrine, which causes uterine contractions and minimizes post-partum haemorrhage. However, this drug also has a pronounced hypertensive and vasoconstrictive effect and so is avoided in most women with heart disease in favour of a slow infusion of syntocinon (an oxytocin analogue)(Cauldwell et al., 2017).

The delivery and immediate postpartum period is associated with further profound and rapid changes in the circulatory system. During delivery, cardiac output, heart rate, blood pressure, and systemic vascular resistance increase with each uterine contraction. Obstetric nursing is the specialty dealing with the care of a woman and her offspring during pregnancy, childbirth and the puerperium. This field of nursing is often further specialized into Perinatal Nursing and Labor and Delivery Nursing. Modern day obstetric nurse care begins with the antenatal care which is vital for satisfactory perinatal outcomes (Rodriguez, et al., 2017).

The result of present study revealed that the overall percentages of correct practices related to related to nursing care of cardiac women during fourth stage of labor and post partum which include increased after the intervention program. This result agree with Meah et al., (2016)who concluded that post-partum follow-up is also important to assess for deterioration following pregnancy[ 20] and to monitor for peripartum cardiomyopathy, which can occur late in the post-partum period. Some conditions, such as long QT and Marfan syndrome, seem to be associated with more complications in the post-partum period, and advising women accordingly is important prior to discharge. Post-partum follow- up also allows for the reintroduction of important cardiac medications whose use may have been altered during pregnancy, such as angiotensin-converting enzyme inhibitors or warfarin. Also Post-partum is a key opportunity to discuss contraception and the options available to women to reduce the risk of an unplanned pregnancy, as well as to 
allow recovery from the most recent pregnancy, especially in the context of peripartum cardiomyopathy( Reza et al., 2017).

The result of present study revealed that there were a high positive correlation between total knowledge and practice score of studied nurses at pre and post intervention phase. This may be due to effect of educational program as the improvement of knowledge leading to improve practice. Also the educational session was effective in raising staff nurse awareness. The session shows a significant impact increase of the participants' level of knowledge which reinforces the continuing need for more education about intrapartum care of pregnant women with cardiac diseases. It also increase motivation to further expand their skills, finally the session has a great effect because continuing education plays a significant role in equipping nurses to deal with the major changes currently making an impact on health care. Nurses today need knowledge and skills to perform and practice their job.

\section{Conclusion}

Based on the findings of the current study, the study concluded that research hypotheses are supported and the educational intervention program had appositive effect on improvement of maternity nurses' knowledge and practice regarding management of intrapartum woman with cardiac disease. And in turn their performance toward caring for this high risk group. There was a highly statistical significance difference between pre and post intervention and positive correlation between nurses' knowledge and their practice before and after intervention too.

\section{Recommendations}

In the light of the findings of the current study the following recommendations were be suggested:

- Periodic educational program for nursing staff in Obstetrics and Gynecology Department regarding nursing care of cardiac patients.

- Orientation to the newly jointed nurses about educational program should be held.

- Prepared booklets about nursing intervention of cardiac women during pregnancy and labour should be available to all nurses who work with these cases.

- Provision of systematic, continuous supervision to evaluate the nursing performance for these high risk cases to ensure the provision of quality nursing care.

\section{Further researches:}

- Assessment of the quality of nursing intervention among cardiac women in labour area.

- Effect of nursing care provided to cardiac women durinlabour on mother satisfaction .

- Guidelines for cardiac women about safe pregnancy and labour

\section{Acknowledgement :}

The authors would like to express their appreciation and gratitude to all nurses who willingly participated in the study.

\section{References}

Anderson, H., \& Haythe, J. (2016). 13Facts every woman should know About How Heart Disease Affects Her. International Medicine J. Philadelphia. Retrieved March 15, 2016, from Bermudian.com

Beth Ann White. (2016). Nursing Knowledge of Heart Failure. Doctor of Nursing Practice. West Virginia University.

Cauldwell, M., Steer, P.J., Swan, L., Uebing, A., Gatzoulis, M.A., \& Johnson, M.R. (2017). The management of the third stage of labour in women with heart disease. Heart, 103, 945-951. https://doi.org/10.1136/heartjnl-2016-310607

Centers for Disease control and Prevention. (2015). Interactive atlas of heart disease and stroke tables. Retrieved March 26, 2015, from http://nccd.cdc.gov/DHDSPAtlas/Reports.aspx

Clinical practice guideline. (2016). Heart disease in pregnancy (2nd ed.). This guideline present best clinical practice in the management of heart disease during pregnancy, labour and post partum.

Deen, J., Chandrasekaren, S., Stout, K., \& Easterling, T. (2017). Pregnancy and Coexisting Disease, Heart Disease During Pregnancy. EKB Data Centre, Elsevier. Retrieved from ClinicalKey.com 
Eman, E.M., \& Hala, I.Z. (2013, December). Impact of Intervention Program on Nurse's Knowledge and Practice Regarding Nursing Care of Pregnant Cardiac Patients during Labor. Med. J. Cairo Univ., 81(2), 141-153.

Emmanuel, Y., \& Thorne, S.A. (2015). Heart disease in pregnancy. Best Pract Res ClinObstet Gynaecol, 29, 579-597.https://doi.org/10.1016/j.bpobgyn.2015.04.002

Esteves-Pereira, A.P., Deneux-Tharaux, C., Nakamura-Pereira, M., Saucedo, M., Bouvier-Colle, M.H., \&Leal, Md.C. (2016). Cesarean delivery and postpartum maternal mortality: a population-based case control study in Brazil. PLoS One, 11, e0153396.https://doi.org/10.1371/journal.pone.0153396

Gelson, E. (2011, January). Cardiac disease in pregnancy. Obstetrics\& Gynecology Journal. https://doi.org/10.1576/toag.9.2.083.27308

Guidline scope. (2015). Intrapartum care for high risk women-draft scope for consultation (13 August To 11 September 2015).

Laura, L., Hayman, K.B., Barbara, J., \& Fletcher, N.H.M. (2015). The role of nurses in Promoting Cardiovascular Health Worldwide the Global Cardiovascular Nursing. Journal of the American College of Cardiology, 66(7).

Meah, V.L., Cockcroft, J.R., Backx, K., Shave, R., \& Stohr, E.J. (2016). Cardiac output and related haemodynamics during pregnancy: a series of meta-analyses. Heart, 102, 518-526.https://doi.org/10.1136/heartjnl-2015-308476

Michael Nanna and Kathleen Stergiopoulos. (2014). Pregnancy Complicated by Valvular Heart Disease: An Update. J Am Heart Assoc., 3. Retrieved June 5, 2014, from http://jaha.ahajournals.org/content/3/3/e000712

Mozaffarian, D., Benjamin, E.J., Go, A.S., Arnett, D.K., Blaha, M.J., Cushman, M., ... Turner, M.B. (2015). Heart Disease \& stroke statistics-2015 update: a report from the american heart association. Circulation, $131,329-322$.

MporarBrickner, B. (2018). Cardiovascular morbidity and mortality in pregnancy. Contemporary OB/GYN. Retrieved January 11, 2018, from http://www.contemporaryobgyn.net/modern-medicine-feature-article

Pieper, P.G. (2012, January). The pregnant women with heart disease: management of pregnancy and delivery. Neth Heart J., 20(1), 33-37.https://doi.org/10.1007/s12471-011-0209-y

Reza, A., \& Stephanie, L.C. (2017). Heart Disease and Pregnancy. CardiolTher, 6, 157-173.https://doi.org/10.1007/s40119-017-0096-4

Rodriguez, V., Weiss, M.C., Weintraub, H., Goldberg, I.J., \& Schwartzbard, A. (2017). Cardiovascular disease leads to a new algorithm for diabetes treatment. Journal of Clinical Lipidology, 11(5), 1126-1133.https://doi.org/10.1016/j.jacl.2017.07.004

Royal College of Obstetricians and Gynaecologists. (2011, June). Good Practice No.13, Cardiac Disease and Pregnancy.

Ruys, T.P.E., Roos-Hesselink, J.W., Pijuan-Dome`nech, A., Vasario, E., Gaisin, I.R., Iung, B., ... Johnson, M.R. (2015). Is a planned caesarean section in women with cardiac disease beneficial?. Heart, 101, 530-536.https://doi.org/10.1136/heartjnl-2014-306497

Steer, P.J., Gatzoulis, M.A., \& Baker, P. (2012). Heart Disease and Pregnancy. London: RCOG Press.

Sunitha, M., Chandrasekharappa, S., \& Brid, S.V. (2014). ElectrocradiographicQrs Axis, Q wave and T-wave changes in 2nd and 3rd trimester of normal pregnancy. J ClinDiagn Res, 8, 17-21.

Uri, E., Sorel, G., Petronella, G.P., \& Candice, K.S. (2016). High-Risk Cardiac Disease in Pregnancy. Journal of the American College of Cardiology.

Valiani, M., Rezaie, M., \& Shahshahan, Z. (2016). Comparative study on the influence of three delivery positions on pain intensity during the second stage of labor. Iranian Journal of Nursing and Midwifery Research, 21(4), 372.https://doi.org/10.4103/1735-9066.185578

Vassilis, I.B. (2018). Cardiovascular disease and pregnancy: what to know an article from the e-journal of the ESC. Council for Cardiology Practice, 12, 10-16.

Victor, G., Sommer, J., \& Khan, F.H. (2016). 21st Century Nurse's Role in Decreasing the Rising Burden of Cardiovascular Disease. Anaesthesia, Pain \& Intensive Care, 20(4), 503-510. 
Wald, R.M., \& Colman, J.M. (2017). Pregnancy and contraception. In Warnes, C.A. (Ed.), Adult Congenital Heart Disease. Oxford, 20095, Wiley-Blackwell.

Whitte, R., Hobbins, J., \& Engle, M. (2015). Pregnancy and its outcome in women with and without surgical treatment of congenital heart disease. Am J Cardiol, 50, 641. https://doi.org/10.1016/0002-9149(82)90334-4

WHO, the world health report. (2016). Mother and child health. World health organization.

\section{Copyrights}

Copyright for this article is retained by the author(s), with first publication rights granted to the journal.

This is an open-access article distributed under the terms and conditions of the Creative Commons Attribution license (http://creativecommons.org/licenses/by/4.0/). 